\title{
Evaluation of Neotectonic Signature Using Morphometric Indicators: Case Study in Nefza, North-West of Tunisia
}

\author{
Slimen Sedrette ${ }^{1}$, Noamen Rebaï ${ }^{2}$, Mohamed Mastere ${ }^{3}$ \\ ${ }^{1}$ Department of Geology, El Manar University, El Manar, Tunisia \\ ${ }^{2}$ Department of Civil Engineering, El Manar University, El Manar, Tunisia \\ ${ }^{3}$ National Institute for Urban and Territorial Planning (INAU), Laboratory of Geomatic, Rabat, Morocco \\ Email: ssedrette@gmail.com
}

Received 9 March 2016; accepted 3 June 2016; published 6 June 2016

Copyright (C) 2016 by authors and Scientific Research Publishing Inc.

This work is licensed under the Creative Commons Attribution International License (CC BY). http://creativecommons.org/licenses/by/4.0/

\section{(c) (i) Open Access}

\begin{abstract}
Neotectonic activity can be deduced from stream network patterns and as an outcome of its evolution. The objective of this study is to investigate the use of the stream network morphology and morphometric methods to assess neotectonic signatures in Nefza region situated in North- West of Tunisia. For this aim, a Digital Elevation Model (DEM), hydrographic layers extracted from Nefza topographic map $(1 / 25,000)$, lithology and tectonic lineament parameters extracted from the geologic map $(1 / 50,000)$ were used. The objective of this paper is to map structural and lithological discontinuities of the study area, by the morphostructural analysis of the topography extracted of DEM as well as the drainage anomalies. This work allowed the characterization of discontinuities of lithologic and structural origin. The previously conducted studies in the study area, confirm that is crossed by lineaments at several directions E-W, N-S, NE-SW and NW-SE. Based on the results obtained from this study regarding the correlation between tectonic and hydrographic network, we can highlight a regional rejuvenation tendency of the most mapped lineaments.
\end{abstract}

\section{Keywords}

Morphometry, Hydrographic Network, DEM, Drainage Anomalies, Neotectonic, Nefza

\section{Introduction}

The major factors governing the evolution of landscape are tectonics and/or climate and the variation in lithology [1]. Morphometry is the measurement and mathematical analysis of the configuration of the earth's surface,

How to cite this paper: Sedrette, S., Rebai, N. and Mastere, M. (2016) Evaluation of Neotectonic Signature Using Morphometric Indicators: Case Study in Nefza, North-West of Tunisia. Journal of Geographic Information System, 8, 338-350. 
shape and dimensions of its landforms [2].

The identification of geomorphological characteristics in the tectonic dominated landscape is possible via the estimation of commonly used morphotectonic indices in active tectonic research [3]-[5]. Morphotectonic indices are reconnaissance tools to evaluate the relationship between tectonics and basin morphology and to identify recent geological deformation [5].

The present study is an attempt to investigate the use of numerical geomorphometric methods to extract neotectonic signature in Nefza region (North-West of Tunisia).

Except its role in shaping the topography, the drainage network is the main controlling factor of the coupling between surface processes and deep crustal deformation, as well as of the relations between tectonics and climate variations, and the sedimentary record in basins [6]. Regional analysis of drainage basin and river valley morphology helps to define differential uplift in many tectonically active regions. In south India Sreedevi [7] applied a morphometric analysis in the semi-arid Wailapalli basin, using morphometric indices that showed the basin development to be mainly guided by the effect of faulting and thrusting. The influence of subsurface structural features on the overall architecture of the watershed basins and channel patterns were studied.

Hypsometric analysis is an important tool to assess and compare the geomorphic evolution of various landforms irrespective of the factor that may be responsible for it. In rapidly uplifted regions, such as Siwalik Hills in Nepal and Western Foothills of Taiwan, hypsometric integral (HI) proved to be highly correlated with the uplift rate and recently uplifting anticline respectively [8] [9].

Differences of Hypsometric Curve (HC) and Hypsometric Integral (HI) values are related to the degree of disequilibrium in the balance of erosive and tectonic forces [10]. Willgoose and Hancock [11] used a mathematical model to show that the hypsometric curve depended on the drainage network, the landscape runoff processes and the basin's geometry. Based on a mathematical model, they also deduced that the HI would be positively correlated with uplift rate.

In our study, we performed the analysis using topographic and geologic map. GIS technique is a speed, precision, fast and inexpensive way for calculating morphometric analysis [12].

We examine variations in the hypsometric characteristic for the different catchment area of the Nefza region in order to differentiate clusters of high or low hypsometric values and to evaluate their significance in relation with lithology and tectonics. The structural style of the region object of our study is characterized by folds and faults at several directions. The analysis of geomorphic features, such as lineaments and drainage patterns, can provide insights into the tectonic setting and landscape evolution of a region [13]. So, relations between drainage network, drainage anomalies and regional structural lineament in Nefza region were studied. The drainage anomalies are defined as a local deviation of the regional drainage and/or of the style or runoff model, and this is in agreement with the regional and/or topographic structure [14]. These drainage anomalies may have structural or lithological origins and can also be induced by erosion [15]-[18]. Indeed, several research studies used drainage anomalies to detect neotectonic activity [18]-[20]. Ben Hassen [21] used a semi-automatic methodology to extract drainage anomalies network from the southern Atlas of Tunisia known for its relatively high seismicity. This method allows deducing the reactivation of one (or several) branch (es) of the Gafsa fault.

\section{Study Area}

The investigated area is located in the North East of Tunisia and enclosed between latitudes $8^{\circ} 48^{\prime} 08^{\prime \prime} \mathrm{E}$ and $9^{\circ} 10^{\prime} 35^{\prime \prime} \mathrm{E}$ and longitudes $36^{\circ} 53^{\prime} 34^{\prime \prime} \mathrm{N}$ and $37^{\circ} 05^{\prime} 30^{\prime \prime} \mathrm{N}$, covering an area of $513.8 \mathrm{sq}$. $\mathrm{km}$. The area enjoys sub-humid climate with $900 \mathrm{~mm}$ average annual rainfall. The geologic map of Nefza district covered a party of the Maghrebide belt running E-W in the Western Mediterranean (Figure 1). It resulted from the collision between the African plate (Gondwana supercontinent) and the Meso-Mediterranean micro-plate called derived from the European continent during the Neo-Tethysian oceanic aperture in the Early Jurassic. The structural history of this region was generated according to three main steps [22]:

-In the late Cretaceous period, the subduction of the Tethyan oceanic strip, which separated Gondwana from Alkapeca resulted in a flysch accretion prism ("Kabylianflyschs") in the Eastern Maghrebides;

-Docking of the Alkapeca domain (Middle Eocene-Early Oligocene) with the Africa margin, altogether deformed [23];

-The Alpine phase (Latest Burdigalian-Early Serravallian) resulted from the collision between the dismembered Alkapeca and Africa domains. 


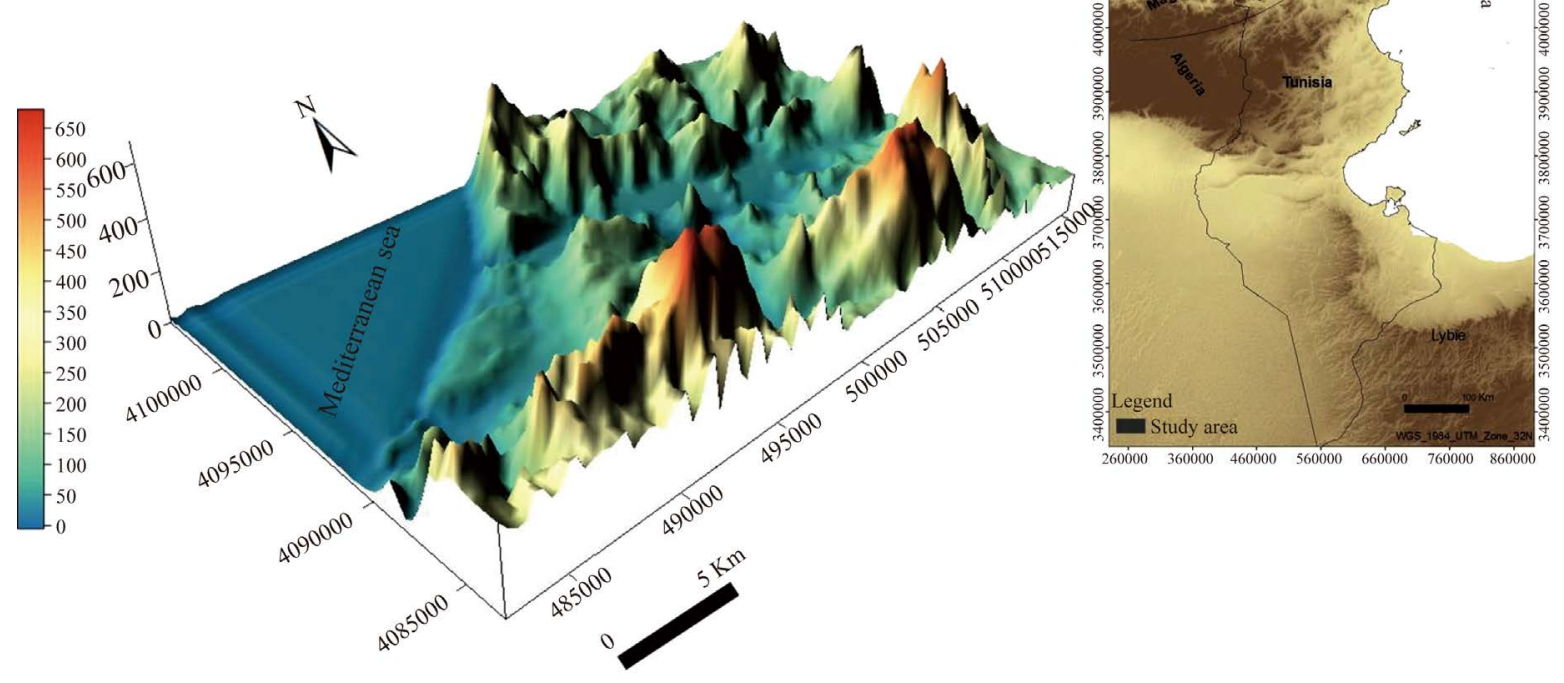

Figure 1. Location and Digital elevation model of the study area.

Also, the geology of the region is characterized by several structural features that are usually associated with the phenomena responsible for the development of polymetallic mineralization, well as the transfer and dispersion on the surface of various geochemical elements. During Neogene, when the Nefza magmatism emplaced [24], there was an alternation of oblique compressive regime and extension regime, which is typical of the postcollisional period. Most important, during the Serravallian and the Tortonian periods, the northern African realm was affected by a very oblique compressive regime [25], and experienced short-lived returns to extensional conditions during the Messinian and Pliocene periods. Since then, the Africa-Europe convergence rate has been very low $\left(0.5 \mathrm{~cm} \cdot \mathrm{a}^{-1}\right)$ and the plate boundary is still located at the front of the Tellian Zone [26], with some folding just to the north of the coastline. In the Northern Tunisian Tell region, studied here, the sedimentary substrate comprises the Ed Diss thrust sheet (Upper Cretaceous to Eocene) overlain by the Numidiannappe [8]. The latter consists of a thick ( $\geq 1000 \mathrm{~m}$ ) series of siliciclasticflysch (Numidianflysch), Oligocene to Lower Miocene (Burdigalian). The geological and the complex tectonic setting of this region, determines the increased tectonic activity, making it an ideal study region for testing neotectonic deformation.

\section{Materials and Methods}

In this study, we used topographic data extracted by manually vectorisation of elevation contours (with equidistance curves equal to $25 \mathrm{~m}$ ) and the drainage network system from the four topographic maps at 1/25,000 covering the study area.

The second datasets to be acquired for this study were the digital scanned geological maps were imported into ArcGIS to create the necessary vector data. This digital scanned map was useful for the digitization of lithology and faults as vector data. SRTM data was also used.

Topographic maps, geologic map and digital satellite data were geometrically rectified and georeferenced to world space coordinate system UTM (Universal Transverse Mercator)/WGS84 (World Geodetic System) using digital image processing software.

For proper determination of flow direction and flow accumulation, DEM sinks were identified and filled. To obtain the drainage basins; depressions were eliminated. Based on the flow direction model, calculated using the D8 algorithm [27], a minimum accumulation area threshold was established. The contributing drainage area of every cell was computed and the catchments were defined and numbered to facilitate analysis. Boundaries of the 68 subwatersheds were derived.

Various types of morphometric indicators have been carried out in this study to evaluate relief characteristic and to examine hydro-geomorphological responses to tectonic deformation at a regional scale. 
The area (A), within the drainage basin boundary and the perimeter (P) corresponding to the total length of the drainage basin boundary is automatically generated by SIG software.

An overall evaluation of the relief (elevation and slope) can be helpful for understanding better the physiographic nature of the study area. Slope grid is identified as the maximum rate of change in value from each cell to its neighbors, using methodology described in Burrough [28]. The following indices are a first sight evaluation of relief structure and its interactions with the drainage network.

Hypsometric analysis is an important tool to assess and compare the geomorphic evolution of various landforms irrespective of the factor that may be responsible for it. The major factors governing the evolution of landscape are tectonics and/or climate and the variation in lithology.

Several studies have demonstrated the utility of hypsometric analysis in tectonic interpretation. High HI values have generally been associated with higher rates of tectonic activity.

The hypsometric curve $(\mathrm{HC})$ is generated by plotting the relative drainage basin height $(\mathrm{h} / \mathrm{H})$ that is known as the total basin height ratio against the relative drainage basin area $(\mathrm{a} / \mathrm{A})$ which is the total basin area ratio [29]. It describes the distributions of elevations across an area of land, from one drainage basin to entire planet. These curves have been used to infer the stage of development of the drainage network also it is a powerful tool to differentiate between tectonically active and inactive areas [29].

The hypsometric integral and its relationship to the degree of dissection allow it to be used as an indicator of a landscape's stage in the cycle of erosion. The theoretical evolution of the stage of a landscape is: youthful stage, characterized by deep incision and rugged relief, mature stage, where various geomorphic processes operate in near equilibrium, and old stage, distinguished by a landscape near base level with very subdued relief [29] [30].

It is simply defined as the area under the hypsometric curve and calculated as follow:

$\mathrm{HI}=($ mean elevation - minimum elevation $) /($ maximum elevation - minimum elevation $)$

Determining the hypsometric integral (HI) is a powerful technique that reveals the degree of disequilibrium in the balance of erosive and tectonic forces [30] [31]. The values depend on various factors, such as rock resistance, and cannot be related directly to active tectonics.

In general, high values of the hypsometric integral are convex, and these values are generally $>0.5$. Intermediate values tend to be more concave-convex or straight, and generally have values between 0.4 and 0.5 . Finally, lower values $(<0.4)$ tend to have concave shapes [32].

The contrasts in lithology or the presence of faults help the streams to reach a new equilibrium condition. The interpretation of the resulting geomorphic indices extracted from stream shape reveals information that is needed for the final evaluation of potential regional tectonic deformation.

The use of GIS is particularly helpful for determining major directions followed by the stream network and to identify the influence of tectonics on the river stream network.

Also, rivers are very sensitive to topographic changes caused by uplift or subsidence and are thus ideal markers to identify recent tectonic activity [3]. These drainage anomalies may have structural or lithological origins and can also be induced by erosion [15]-[18] [33] [34].

To define all segments with abnormal drainage, we proceeded according to the protocol developed by Ben Hassen [8] for the semi-automatic extraction of drainage anomalies.

This protocol consist that to obtain the regional orientation map of the region, we began by calculating the summit level map [33] [35]-[39]. This map was generated according to the methodology adopted by Slama [20]. From this map, we calculated the orientation map (or exposure) that represents the direction of a slope in the most downward slope [21].

According to Ben Hassen [21] approach, the orientation map is converted from his original raster format to vector format (polygons) with each polygon contain the orientation value of the terrain. Based, both, on the vector layer containing the resultant drainage network and the layer of the orientation of summit level map, the next step is to set, for each drain, the orientation of the summit level map that it crosses.

The intersection of the drainage network and the vector layer of the summit level map will lead to the subdivision of each drain in many segments, each with a value of the summit level map. So, each segment of drainage will be assigned the value of direction.

Subsequently, the attribute table of the drainage network well contains two fields: the flow direction of the drain and the orientation of the summit level map that supports it. From these two fields, a third field is calculated by assigning the value of the difference between the two angles. Finally, referring to the definition of drainage anomaly [16] [39], flow will be assumed that abnormal if the difference is between $\left(-270^{\circ}\right.$ and $\left.-90^{\circ}\right)$ or 
$\left(90^{\circ}\right.$ and $\left.270^{\circ}\right)$.

\section{Results and Discussions}

The Nefza grid map shows that elevations range between $3 \mathrm{~m}$ under sea elevation and $685 \mathrm{~m}$ (Figure 2). The region is characterized by two types of relief: a mountainous area especially in the south dominated by Jbel Khreroufa and Ragoubet El Alia whose summit rises to over $685 \mathrm{~m}$ (Figure 2) and a plain, occupying the central part of the map. The average elevation is $157 \mathrm{~m}$.

The region area slope varies from $0^{\circ}$ to $39^{\circ}$ with a mean slope of $6.89^{\circ}$ and Slope Standard Deviation 5.29 . A high degree of slope is noticed spatially in the south parts of the region (Figure 2).

The slope map is classified into four classes based on slope degree. The very low slopes $(<10 \%)$ are mainly associated with valley fills. The low slopes $(10 \%-20 \%)$ observed in undulating pediplain areas. The moderately sloping areas $(20 \%-25 \%)$ are in association with pediment. Steep slopes $(25 \%-30 \%)$ and very steep slope $(>30 \%)$ are associated with high relief region (Jbel Khreroufa), structural hills, and escarpments. This map is reclassified by giving more importance to areas having steeper slope. The structural style of Nefza region is characterized by the presence of anticlines with curved axes at several directions. We can note also some anticlines associated with Triassic salt tectonics, like Jbel Dougass, Jbel Khriroufa and Ragoubet El Alia. The study area is characterized also by board synclines.

\subsection{Drainage Basins Analysis}

The drainage basin analysis is based on geomorphic indices, such as stream network or drainage basins.

Interpretation of the resulting geomorphic indices reveals information that is needed for the final evaluation of potential regional tectonic deformation within the drainage basins. Indeed, the study area contains 68 basins (Figure 3) with varied size, lithology and age.

Morphological characteristics like area within the drainage basins and perimeter imply information regarding the overall scale of the drainage basins and their spatial size extent [27].

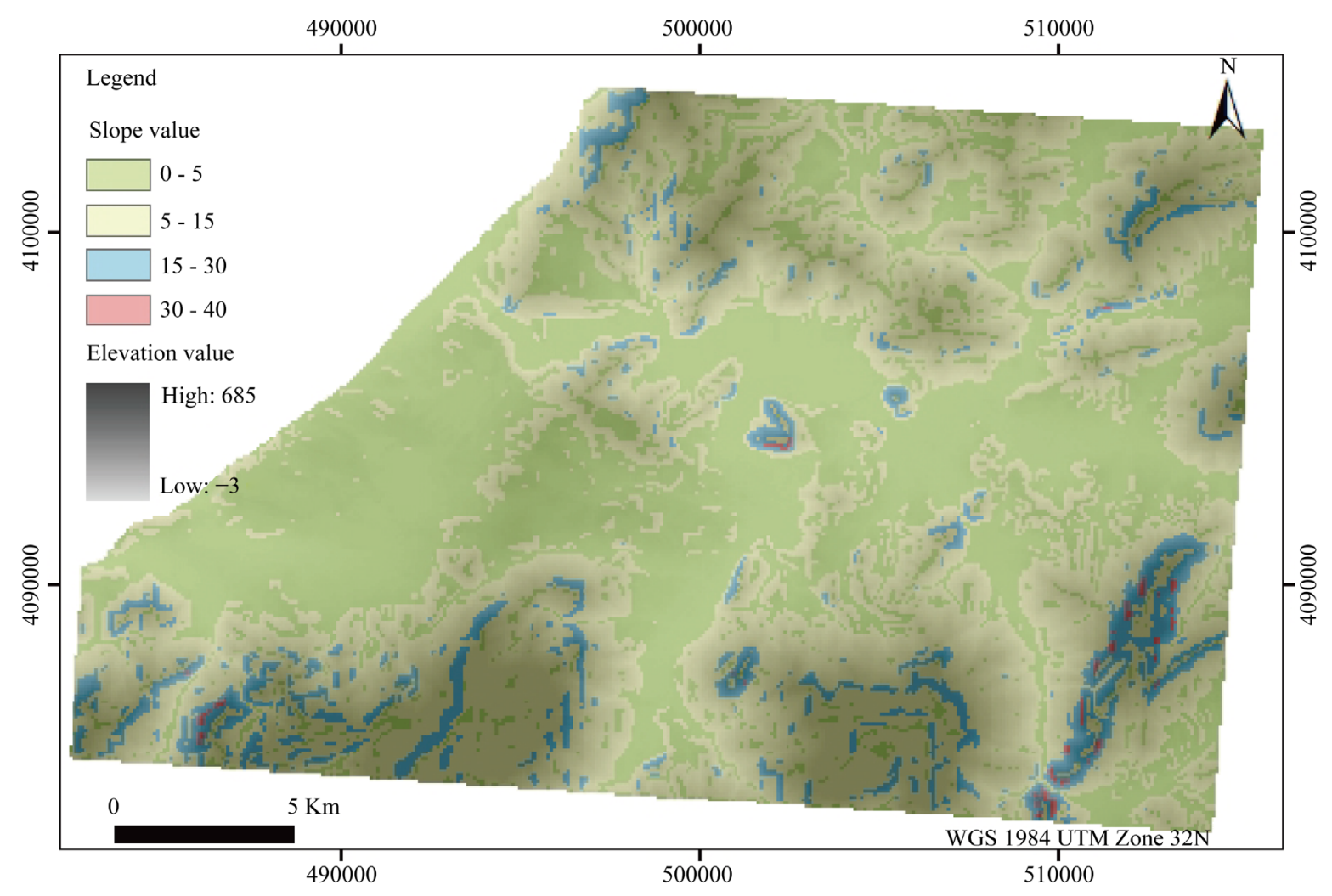

Figure 2. Slope Map of study area with elevation value. 


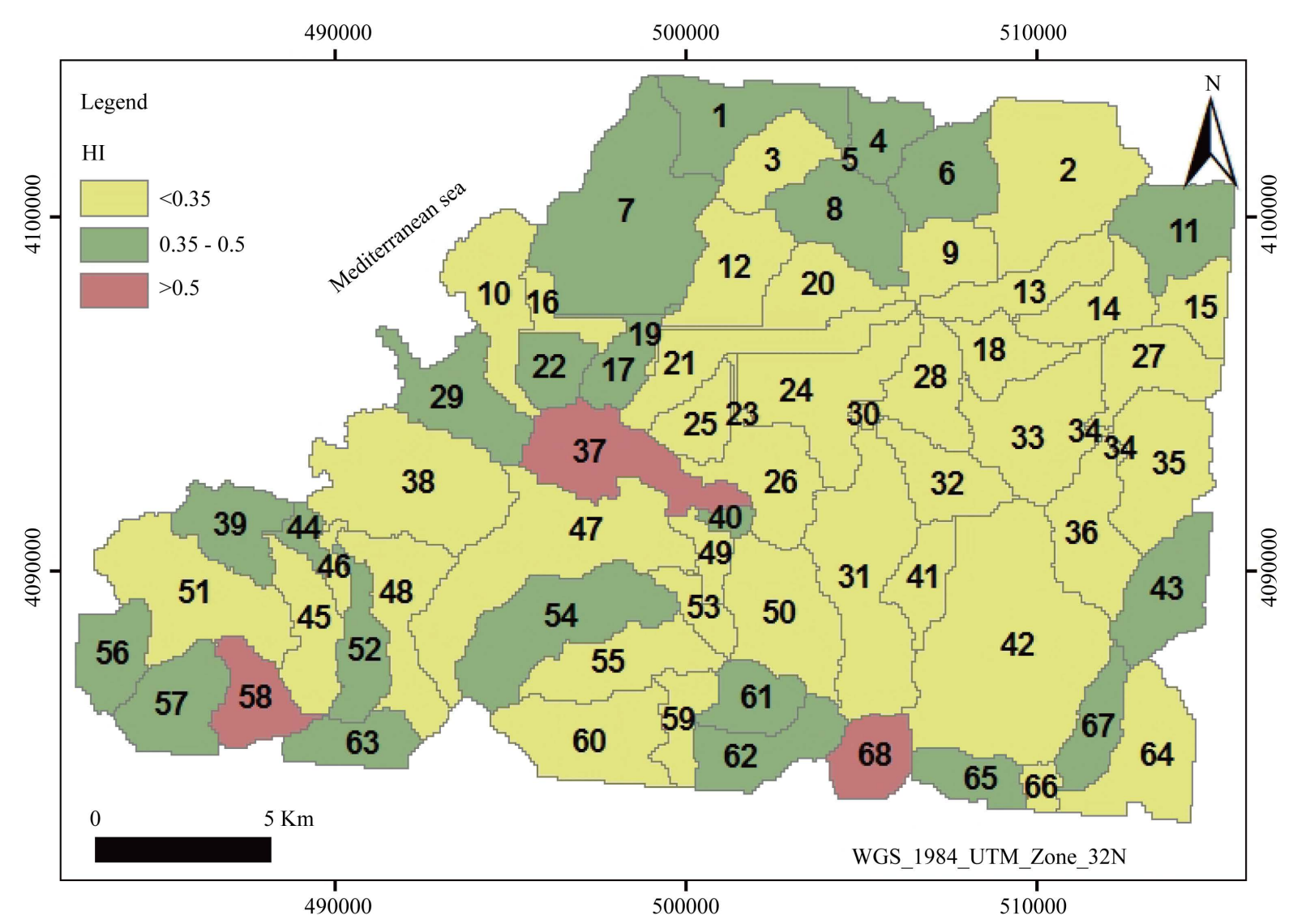

Figure 3. Hypsometric catchments proprieties of Nefza region.

Regarding the basins area size, the largest ones are $n^{\circ} .42,7,47,31,38$ and 2 with the smallest ones being $n^{\circ}$. $5,19,23,34$ and 30 .

The resultant hypsometric curve graph has shown that "S" shaped, concave and convex hypsometric curve which mean that the erosional process differs from one basin to another.

The calculation and classification of hypsometric integrals (HI) for the drainage basins of the study area is presented in Figure 3.

The hypsometric analysis of the various watersheds of the Nefza region relief shows three trends (Figure 3):

- Red areas (basin 58,68 and 37) with deep incision and slight soil erosion;

- Green basins (22 basins) are in the intermediate stage, with moderate incision and erosion (maximum threshold 50\%);

- Yellow basins (43 basins) are in the severe stage of erosion, with low relief (maximum threshold 35\%).

The HI implies to high rates of tectonic activity and provides high relief when the index exceeds 0.5 values [29] [32], such as basins 37, 58 and 68. Lower values of $\mathrm{HI}(<0.35)$ characterize the important number of basins, indicating their mature stage with low relief and undergoing severe erosion.

Most of the basins show sigmoid HC evolving towards an equilibrium state between the endogenous and exogenous process.

Concerning watersheds number 37, 58 and 68 with HI value around 0.6 and convex HC (Figure 4), this reflect a structural or lithological control.

To study a detailed analysis for lithological influence on HI value distribution, we correlate the lithology with the HI values obtained for basins with high HI value and convex HC. This lithological analysis was carried out on the basis of 1:50.000 geologic maps (Figure 5).

Indeed, basin number 58 is covered by salt-intrusion in major proportion, clay and sandstone, marlstone, sandstone, carbonate and slop deposit (Table 1). In this case the lithological characteristics of the land and especially the hardness of the Triassic salt-intrusion rock can be a factor to explain youthful stage of this basin. 


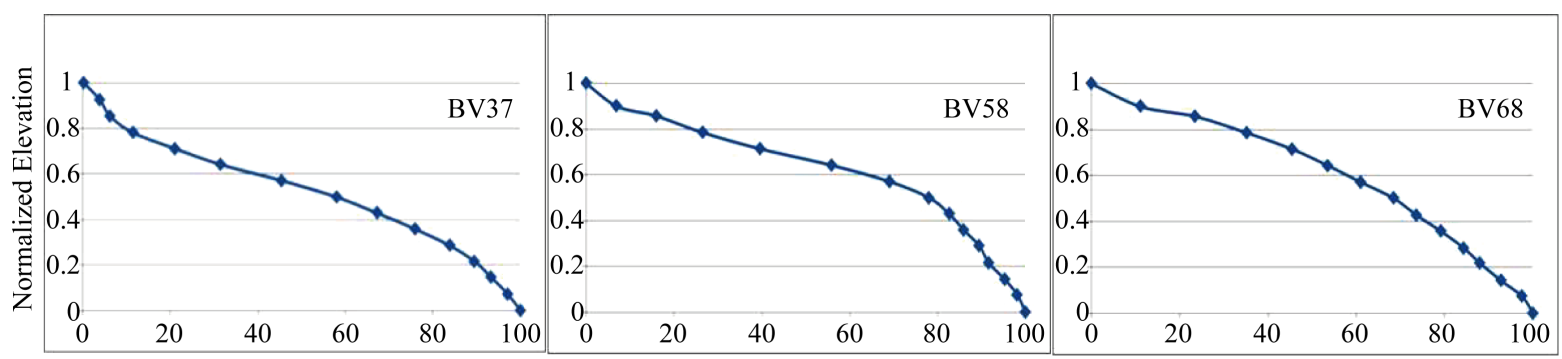

Normalized Cumulative Area

Figure 4. Hypsometric curve of catchment area 37, 58 and 68.

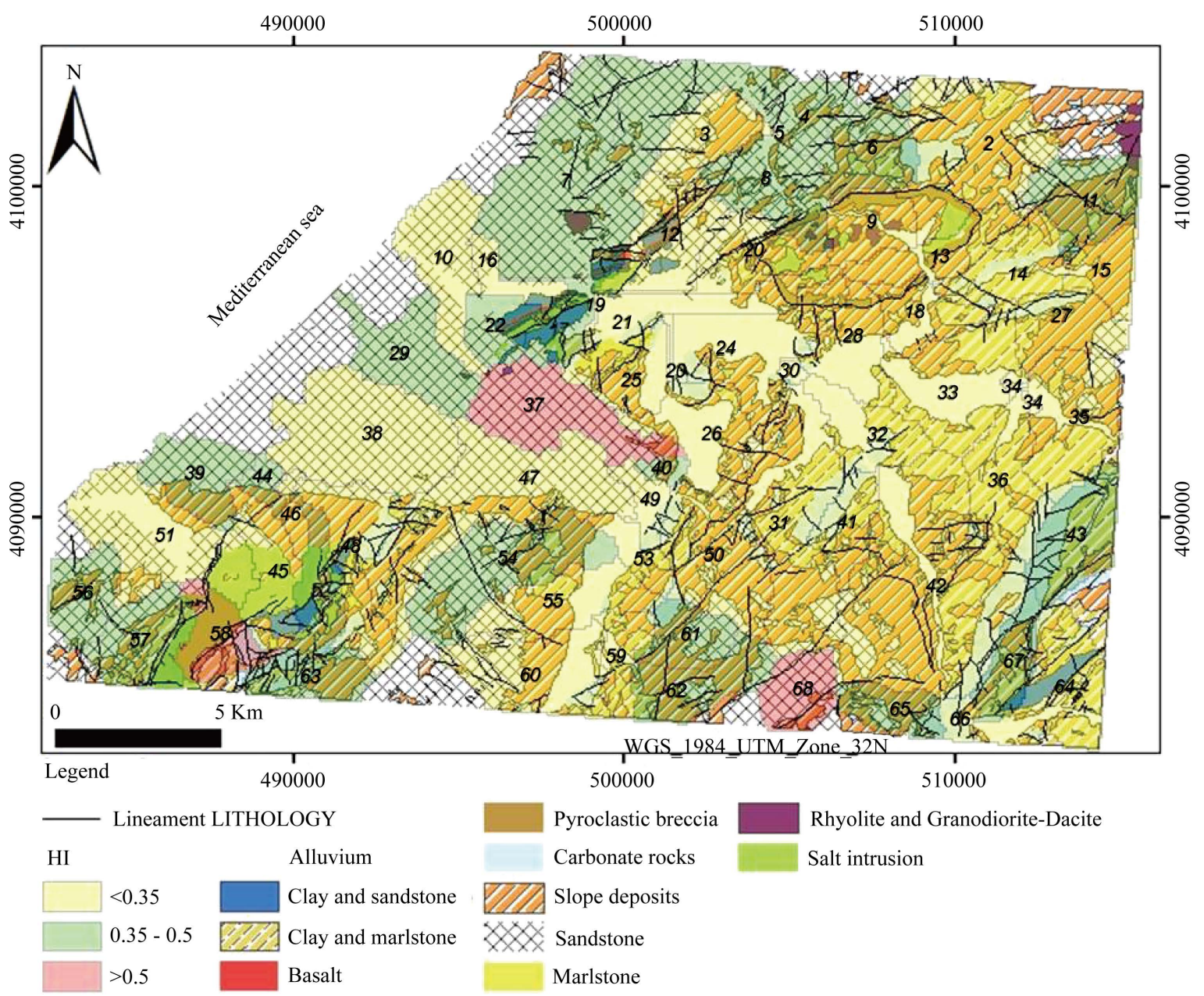

Figure 5. Geological map of Nefza region showing the distribution of the hypsometric property of each catchment.

Whereas, the both basins number 37 and 68 are covered especially by sandstone. In another hand, lithological analysis of the various basins of the region shows other basins $(38,39,44, \ldots)$ covered by the same type of rock and almost with the same proportions but showing an HI lowers than 0.5 . In this case, the lithological factor alone cannot explain this hypsometric tendency.

The correlation with Nefza tectonic layer allows us to deduce that:

- The watershed number 68 and all basins showing an S-shape HC except basin 29 are crossed by tectonic lineaments. So, the high value of the HI can be the result of active tectonics.

- The absence of apparent tectonic index in basins 37 does not allow us to explain the results of the hypsometric analysis. 
Table 1. Hypsometric and lithological characteristic in each basin.

\begin{tabular}{|c|c|c|c|c|c|}
\hline Basins & Area $\left(\mathrm{Km}^{2}\right)$ & \multicolumn{2}{|c|}{ Lithology \% } & $\mathrm{HI}$ & $\mathrm{HC}$ \\
\hline 37 & 10.23 & $\begin{array}{c}\text { Alluvium } \\
\text { Clay and sandstone } \\
\text { Sandstone } \\
\text { Slope deposits }\end{array}$ & $\begin{array}{c}0.8 \\
0.6 \\
94.1 \\
4.5\end{array}$ & 0.51 & S shape-Convex \\
\hline 58 & 5.33 & $\begin{array}{c}\text { Clay and marlstone } \\
\text { Carbonate } \\
\text { Sandstone } \\
\text { Salt intrusion } \\
\text { Slope deposits }\end{array}$ & $\begin{array}{c}21 \\
13.63 \\
7.8 \\
45 \\
12.57\end{array}$ & 0.59 & Convex \\
\hline 68 & 4.7 & $\begin{array}{l}\text { Sandstone } \\
\text { Slope deposits }\end{array}$ & $\begin{array}{l}87 \\
13\end{array}$ & 0.57 & Convex \\
\hline
\end{tabular}

In the same context, Figure 4 shows many basins covered almost with the same lithological materials and have notable differences in their hypsometric properties like in basins 38, 29 and 37. Indeed, the basin 29 covered with sandstone rocks but characterized by an S-shape HC.

The lack of surface tectonic indicator in basin 37 and also basin 29 does not neglect the idea of a subsurface tectonic control prevailing in these basins, especially that the roofing materials are dominated by old and recent sandstone dunes. Active faults may therefore not be depicted on published geological maps, which are typically based mainly on outcrop fault mapping.

\subsection{Hydrographic Network Analysis}

Several research studies [17] [20] [40]-[42] have shown that the neotectonic has a direct interaction with hydrographic network. Drainage analysis generally provides clues to structural features and lithology [14].

Some results of the morphostructural analysis are difficult to interpret, particularly in the case of very homogeneous surfaces and especially those with very low drain density like basin $n^{\circ} 37$ and 29 in our study area. The hydrographic network map includes all streams whose origin is related to the flow of permanent and temporary waters. The drainage pattern is mainly dendritic to sub-parallel (Figure 6).

Azimuth rose diagrams were produced to analyze the relationship between the main drainage networks and the regional lineament directions. Analysis of the directional distribution of streams network in the study area (Figure 7) have been shown a clear predominance of the direction NS and EW direction. These two major directions are relayed respectively by NW-SE and NE-SW directions.

Indeed, the statistical analysis of the structural lineament layer extracted from the Nefza geologic map [43] reveals that the directions of classes N60, N40 and NS are the major directions of the lineament distribution. The secondary directions are, in ascending order, the EW and NW-SE classes. So, this result indicates a positive correlation between structural geology (faulting, lineament, warping) and the dominant stream orientations. This implies that the tectonic regime has an impact on stream segments of the study area.

\subsection{Drainage Anomalies}

Several studies show that rivers necessarily flow from high to low elevations parallel to the maximum regional slope (regional topographic gradient). All deviations of the stream flow direction from the regional topographic gradient are considered as drainage anomalies related either to structural or lithological discontinuities [17] [44]. However, the drain anomalies (Figure 8) correspond to the obliquely flowing drainage and deviating from orthogonal isohypses of the summit level map and all those flowing against the slope [15] [39]. These drain anomalies are considered by Deffontaines [16] as indicators of a recent neotectonic activity.

The comparison with existing tectonic map shows that portions of drains anomalies are located near to the most important tectonic accidents in the region. Thus, the drainage anomalies reveal the footprint on the landscape of recent tectonic movement.

Statistical analysis of anomalous segments directions reveals preferential directions (Figure 9(a)). Their overall distribution favors the EW and the NW-SE direction. The second major family is materialized by N-S direction. As for the NE-SW direction, it comes third. 


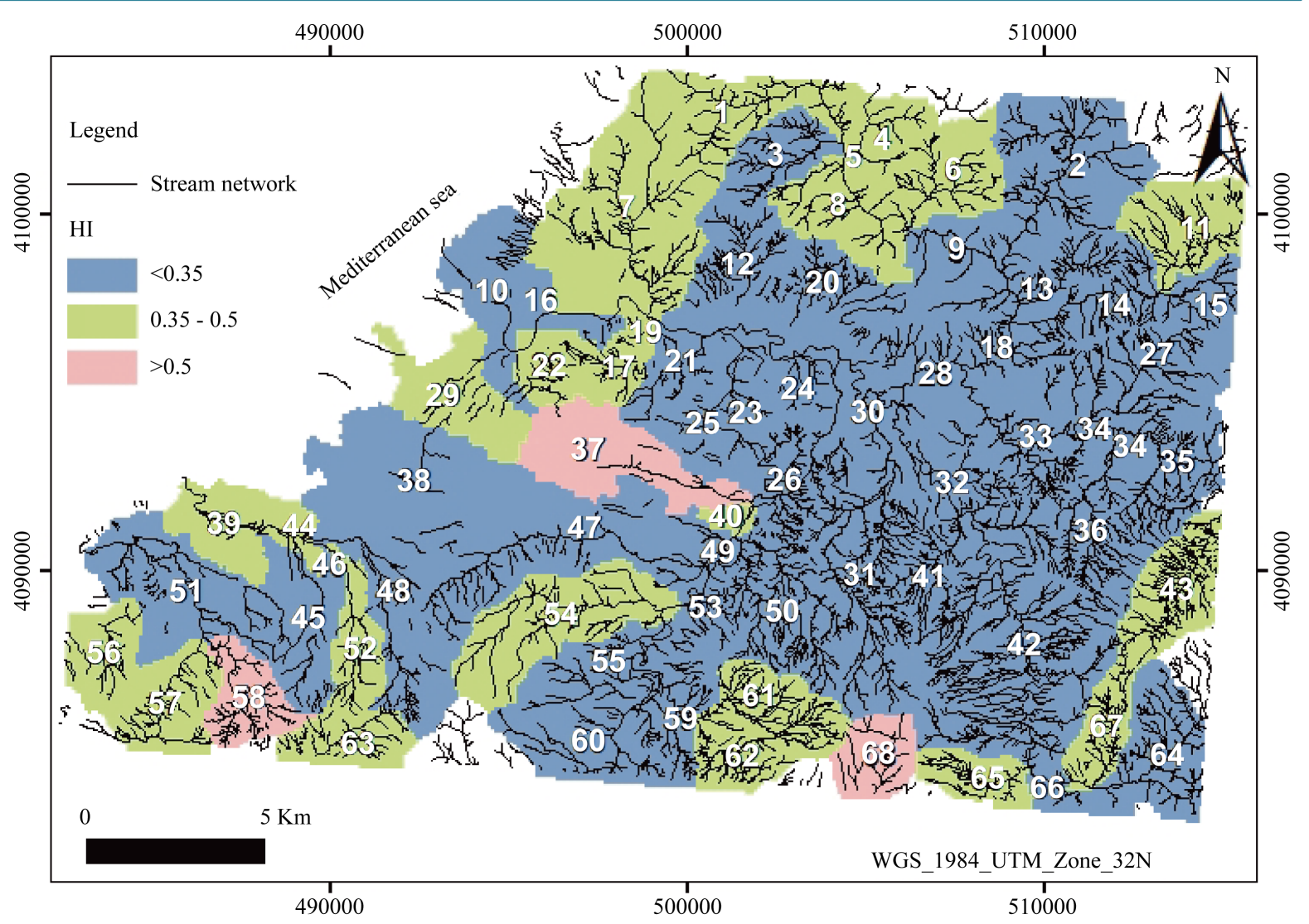

Figure 6. Hydrographic network map.

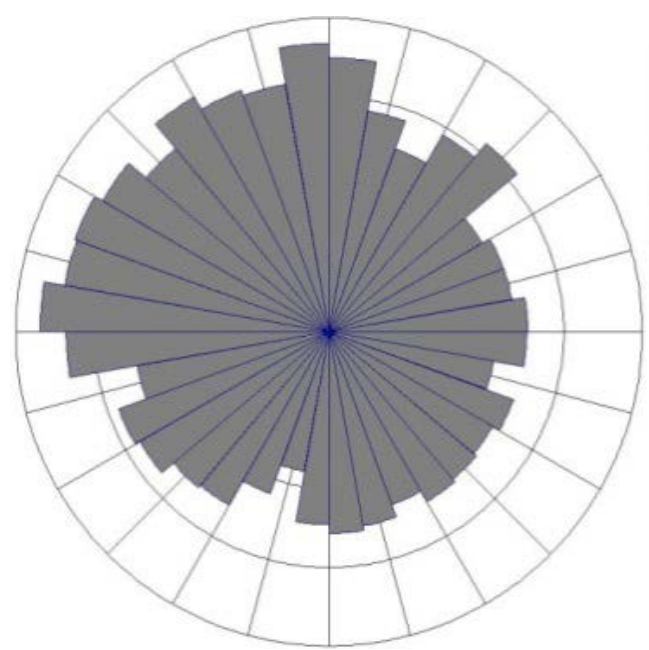

Figure 7. Rose diagram of stream network directions.

In another hand, the distribution of the anomalic drains according to their lengths reveals that the EW direction is the most dominant one (Figure 9(b)). This important direction can be attributable to a recent neotectonic that remobilized an ancient structural orientation.

According to Rekiss [45] works, the EW lineament direction follows up the majority of magmatic outcrop border. This EW direction active during Eocene and Cretaceous times, have been rejuvenated at the end of the Neogene period and during Quaternary in a relay pattern system associated with compressive and extensive deformations according to the alternation of extension and compression phases. 


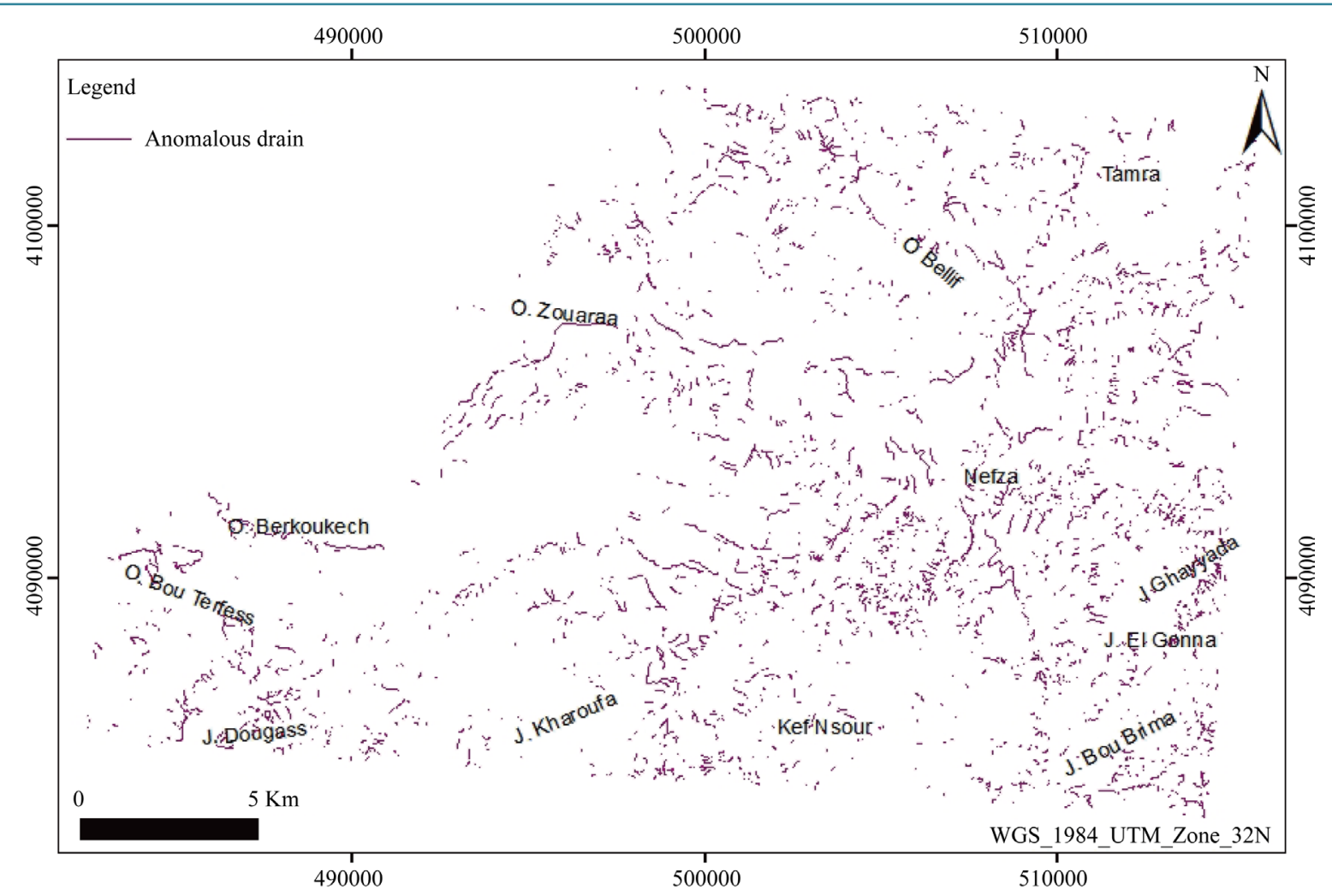

Figure 8. Map of the anomalous drains of Nefza region.
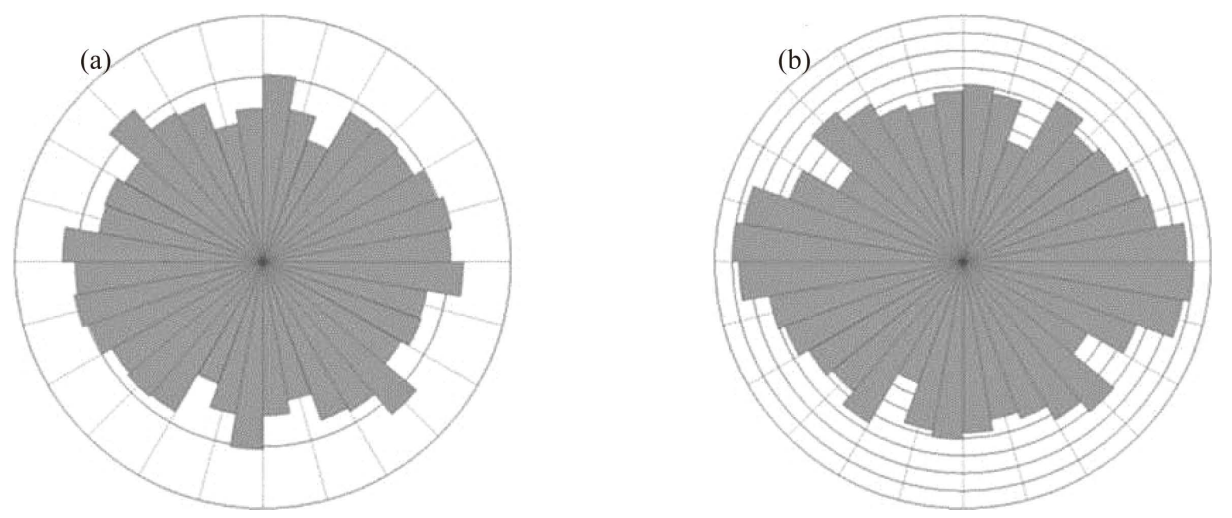

Figure 9. Rose diagram of (a) anomalous streams network directions and (b) the lengths of anomalous drains.

Simultaneous analysis of aeromagnetic and gravity anomalies realized by Jallouli [46] in the Nefza region shows the existence of an intra-sedimentary igneous corp shallow (700 - 800 meters), elongated in the direction N80.

Therefore, the hypsometric observations and the drainage anomalies observed in the watershed 37 and 29 basins area, argues for a subsurface tectonic phenomenon.

Indeed, the magmatic activity already mentioned is associated with a local thermal activity that must be controlled also by fracturing [46].

Indeed, the African-European convergence plate's movement installed in Tunisia since the Cenozoic is expressed by a NW-SE compression phases and sometimes associated with a NE-SW extension [47]-[49]. The persistence until recent period of this phase is shown by seismic activity and several studies confirm the existence of deformations in the ancient and late Quaternary [50]-[52].

The both NS and NW-SE fracturing directions, although it is old, are the most recent tectonic remobilization 
which affected all Tunisia, this tectonic is known as post-Villafranchian stage [52]-[55].

The NE-SW direction, ancient and remobilized during the alpine and atlas stages, corresponds to the Cap Serrat-Ghare Dimaou accident direction crossing the Nefza region. This accident is often the headquarters of Triassic extrusions and magmatic rocks usually accompanied by the establishment of several lead-zinc mineral deposits.

\section{Conclusions}

The analysis of the topographic surface from the Digital Elevation Model and disturbances and anomalies of river system allowed us to distinguish two types of discontinuities: Lithological, structural or even anthropogenic origins (roads, trails, forests limits or cultivated land, transmission lines energy, etc.). These discontinuities result partly from the inherited or the current tectonic activity. The recent to actual nature of a large number of mapped discontinuities is shown by the fact that they pass through different areas of the study area in overlapping and shifting the other pre-existing structures.

The correlation between morphometric study, tectonic and lithology in Nefza district indicates that the high values of $\mathrm{HI}$ and the convex HC characterize fractured zones, the relatively high altitude zones and/or the high resistant rock, except basins 37 and 29. The digitized hydrographic network and the drainage anomalies map are established to evaluate the footprint on the landscape of recent tectonic movement. According to the present study, it has been inferred that major tectonic features have played an important role in shaping the present complex landscape of the Nefza region. The existence of an intra-sedimentary igneous corp elongated in the EW direction mentioned by previous studies may be approved to explain the hypsometric carcteritic of basins 37 and 29. To conclude, we can notify that the morphology of the Nefza region in the Northeast of Tunisia is the result of the dynamic interaction between tectonic, magmatic activity, lithology and fluvial processes.

\section{References}

[1] Babu, K.J., Sreekumar, S., Arish, A. and Midhun, K.P. (2014) Hypsometry and Geomorphic Development of a Watershed: A Case Study from South India. International Journal of Science and Research (IJSR), 3, 1495-1500.

[2] Clark, R.N. and Swayze, G.A. (1996) Calibration to Surface Reflectance of Terrestrial imaging Spectrometry Data: Comparison of Methods, Applied Optics in Preparation.

[3] Burbank, D.W. and Anderson, R.S. (2001) Tectonic Geomorphology. Blackwell Science Ltd., Australia, 160.

[4] Jacques, P.D., Salvador, E.D., Machado, R., Grohmann, C.H. and Nummer, A.R. (2014) Application of Morphometry in Neotectonic Studies at the Eastern Edge of the Paraná Basin, Santa Catarina State, Brazil. Geomorphology, 213, 1323. http://dx.doi.org/10.1016/i.geomorph.2013.12.037

[5] Kale, V.S., Sengupta, S., Achyuthan, H. and Jaiswal, M.K. (2014) Tectonic Controls upon Kaveri River Drainage, Cratonic Peninsular India: Inferences from Longitudinal Profiles, Morphotectonic Indices, Hanging Valleys and Fluvial Records. Geomorphology, 227, 153-165. http://dx.doi.org/10.1016/j.geomorph.2013.07.027

[6] Marc, V.M., Julien, B., Stéphane, D., Jean Van, D.D. and Xavier, L. (2015) Drainage Network Evolution and Patterns of Sedimentation in an Experimental Wedge. Tectonophysics, 664, 109-124. http://dx.doi.org/10.1016/j.tecto.2015.09.007

[7] Sreedevi, P.D., Owais, S., Khan, H.H. and Ahmed, S. (2009) Morphometric Analysis of Watershed in South India Using SRTM Data and GIS. Journal Geological Society of India, 73, 543-552. http://dx.doi.org/10.1007/s12594-009-0038-4

[8] Hurtrez, J.E., Sol, C. and Lucazeau, F. (1999) Effect of Drainage Area on the Hypsometry from an Analysis of Small-Scale Drainage Basins in the Siwalik Hills (Central Nepal). Earth Surface Processes and Landforms, 24, 799808. http://dx.doi.org/10.1002/(SICI)1096-9837(199908)24:9<799::AID-ESP12>3.0.CO;2-4

[9] Chen, Y.C., Sung, Q. and Cheng, K.Y. (2003) Along-Strike Variations of Morphotectonic Features in the Western Foothills of Taiwan: Tectonic Implications Based on Stream-Gradient and Hypsometric Analysis. Geomorphology, 56, 109-137. http://dx.doi.org/10.1016/S0169-555X(03)00059-X

[10] Weissel, J.K., Pratson, L.F. and Malinverno, A. (1994) The Length Scaling Properties of Topography. Journal of Geophysical Research, 99, 13997-14012. http://dx.doi.org/10.1029/94JB00130

[11] Willgoose, G. and Hancock, G. (1998) Revisiting the Hypsometric Curve as an Indicator of Form and Process in Transport-Limited Catchment. Earth Surface Processes and Landforms, 23, 611-623. http://dx.doi.org/10.1002/(SICI)1096-9837(199807)23:7<611::AID-ESP872>3.0.CO;2-Y

[12] Grohmann, C.H. (2004) Morphometric Analysis in Geographic Information Systems: Applications of Free Software 
GRASS and R. Computers \& Geosciences, 30, 1055-1067. http://dx.doi.org/10.1016/j.cageo.2004.08.002

[13] Athanasios, A. (2012) A Methodology for the Rapid Identification of Neotectonic Features Using Geographical Information Systems and Remote Sensing: A Case Study from Western Crete, Greece. Thesis, School of Earth and Environmental Sciences, University of Portsmouth, United Kingdom.

[14] Howard, A.D. (1967) Drainage Analysis in Geologic Interpretation: A Summation. Bulletin of the American Association of Petroleum Geologists, 51, 2246-3428.

[15] Deffontaines, B. and Chorowics, J. (1991) Principles of Drainage Basin Analysis from Multisource Data: Application to the Structural Analysis of the Zaire Basin. Tectonophysics, 194, 237-263. http://dx.doi.org/10.1016/0040-1951(91)90263-R

[16] Deffonataines, B. (1990) Développement d'une méthodologie morphonéotectonique et morphostructurale, Analyse des Surfaces Enveloppes, du réseau hydrographique et des modèles numériques de terrains, Application au Nord-Est de la France. Thèse, Univ. Paris VI, France, 230 p.

[17] Deffontaines, B., Chotin, P., AitBrahim, L. and Rozanov, M. (1992) Investigation of Active Faults in Morocco Using Morphometric Methods and Drainage Pattern Analysis. Geologische Rundschau, 81, 199-210. http://dx.doi.org/10.1007/BF01764549

[18] Bahrami, S. (2013) Analyzing the Drainage System Anomaly of Zagros Basins: Implications for Active Tectonics, Tectonophysics, 608, 914-928. http://dx.doi.org/10.1016/j.tecto.2013.07.026

[19] Ferry, M., Meghraoui, M., AbouKaraki, N., Al-Taj, M., Amoush, H., Al-Dhaisat, S. and Barjous, M. (2007) A 48-KyrLong Slip Rate History for the Jordan Valley Segment of the Dead Sea Fault. Earth and Planetary Science Letters, 260, 394-406. http://dx.doi.org/10.1016/i.eps1.2007.05.049

[20] Slama, T. (2008) Conception orienté objet d'un SIG pour l'analyse quantitative morpho-structurale et morphonéotectonique (tectonique active) de la partie nord-est de la zone des diapirs, Tunisie septentrionale, méthode numérique et applications. These de doctorat en geologie, Universite Tunis El-Manar, Tunis, $476 \mathrm{p}$.

[21] Ben Hassene, M., Deffontaines, B. and Turki, M.M. (2014) Semi-Automated Extraction of Drainage Anomalies. Application to the Center of the Southern Atlas of Tunisia. Géomorphologie: Relief, Processus, Environnement, 20, 3-14.

[22] Rouvier, H. (1977) Géologie de l'extrême nord-tunisien: tectonique et paléogéographie superposées à l'extrémité orientale de la chaîne nord-maghrébine. Thèsed'Etat, Paris VI, Paris, 307 p.

[23] Bouillin, J.P. (1977) Géologie alpine de la petite Kabylie dans la région de Collo et El Milia (Algérie). Thèse Faculté des Sciences, Paris VI, $511 \mathrm{p}$.

[24] Negra, L. (1987) Pétrologie, minéralogie et géochimie des minéralisations et des roches encaissantes des basins associés aux structures tectoniques et magmatiques de l'Oued Bélif et du JebelHaddada (Nord des Nefza, Tunisie septentrionale). Unpublished Ph.D. Thesis, Paris-Sud University, Paris, 223 p.

[25] Benaouali, M., Frizon de Lamotte, D., Roca, E., Bracene, R., Faure, J.L., Sassi, W. and Roure, F. (2006) Post-Cre- taceous Kinematics of the Atlas and Tell Systemsin Central Algeria: Early Foreland Folding and Subduction-Related Deformation. Comptes Rendus Geoscience, 338, 115-125. http://dx.doi.org/10.1016/j.crte.2005.11.005

[26] Jolivet, L. (2008) Géodynamique méditerranéenne. Société Géologique de France, Vuibert, 5-47.

[27] O'Callaghan, J.F. and Mark, D.A. (1984) The Extraction of the Drainage Networks from Digital Elevation Data. Computer Vision, Graphics, and Image Processing, 28, 323-344. http://dx.doi.org/10.1016/S0734-189X(84)80011-0

[28] Burrough, P.A. (1986) Principles of Geographic Information Systems for Land Resource Assessment. Monographs on Soil and Resources Survey No. 12, Oxford Science Publications, New York.

[29] Keller, E.A. and Pinter, N. (2002) Active Tectonics: Earthquakes, Uplift, and Landscape. Prentice Hall Earth Science Series, 2nd Edition, Prentice Hall Inc., Upper Saddle River.

[30] Strahler, A.N. (1952) Hypsometric (Area-Altitude) Analysis of Erosional Topography. The Geological Society of America, 63, 1117-1141. http://dx.doi.org/10.1130/0016-7606(1952)63[1117:haaoet]2.0.co;2

[31] Strahler, A.N. (1958) Quantitative Geomorphology of Drainage Basins and Channel Networks. In: Chow, V.T., Ed., Handbook of Applied Hydrology, McGraw Hill, New York, 439-476.

[32] Hamdouni, R., Irigaray, C., Fernandez, T., Chacon, J. and Keller, E.A. (2008) Assessment of Relative Active Tectonics, Southwest Border of Sierra Nevada (Southern Spain). Geomorphology, 96, 150-173. http://dx.doi.org/10.1016/j.geomorph.2007.08.004

[33] Angelier, J. and Chen, R.F. (2002) Soulèvement et Plissement Tectoniques révélés par Analyse mathématique Empirique de Profils Longitudinaux de rivières: Un cas à Taiwan. Comptes Rendus Geoscience, 334, 1103-1111. http://dx.doi.org/10.1016/S1631-0713(02)01850-3

[34] Ramasamy, S.M., Kumanan, C.J., Selvakumar, R. and Saravanavel, J. (2011) Remote Sensing Revealed Drainage Anomaliesand Related Tectonics of South India. Tectonophysics, 501, 41-51. 
http://dx.doi.org/10.1016/j.tecto.2011.01.011

[35] Pannekoek, A.J. (1967) Generalized Contour Maps, Summit Level Maps, and Stream Line Surface Maps as Geomorphological Tools. Zeitschrift fuer Geomorphologie, 11, 169-182.

[36] Prud'Homme, R. (1972) Analyse Morphostructurale appliqué à l'Aquitaine occidentale et au golfe de gascogne. Définition d'une méthodologie cartographique interprétative. Thèse de Doctorat d'Etat, Université de Bordeaux I., Bordeaux, $365 \mathrm{p}$.

[37] Deffontaines, B. (1985) Proposition d'une méthode géomorphologique permettant une approche de la néotectonique en pays tempéré. Exemple d'application: La région de Fougères (France). Rapport Interne BRGM No. 85, SGN 659 GEO, 107 p. + Annexes.

[38] Carvalho, J. (1995) Extraction automatique d'informations géomorphométriques (réseaux et surfaces enveloppes) à partir de Modèles Numériques de Terrain. Thèse de Doctorat es-Sciences, Université Pierre-et-Marie-Curie, Paris, 172 p.

[39] Dridri, A. and Fedan, B. (2001) Rôle du contrôle structural dans la mise en place du réseau hydrographique de Sebou et d'Inaouène entre Fès et oued Amlil (Maroc). Section Sciences de la Terre, No. 23, Bulletin de 1'Institut scientifique, Rabat, 67-77.

[40] Mastere, M., El Fellah, B., Van-VlietLanoë, B. and AitBrahim, L. (2015) Synergy of Geomatic Tools for Structural Discontinuities Mapping and Analysis. Arabian Journal of Earth Sciences, 5, 31-42.

[41] Mastere, M. (2011) La susceptibilité aux mouvements de terrain dans la province de Chefchaouen, analyse spatiale, modélisation proba-biliste multi-échelle et impacts sur l'aménagement \& l'urbanisme. Thèse de doctorat, Université de Bretagne Occidentale, Brest, $319 \mathrm{p}$.

[42] Comentale, B. (1999) Néotectonique et réseau hydrographique: l'exemple du Matese (Apennin Campanien Septentrional, Italie). Géomorphologie: Relief, Processus, Environnement, 5, 359-373. http://dx.doi.org/10.3406/morfo.1999.999

[43] Sedrette, S., Rebai, N. and Turki, M.M. (2015) Développement d'une approche quantitative d'extraction semiautomatique des accidents tectoniques de la carte géologique de Nefza au 1/50 000 en format shp. Arabian Journal of Earth Sciences, 2, 53-64.

[44] Pubellier, M., Deffontaines, B., Quebral, R. and Rangin, C. (1994) Drainage Network Analysis and Tectonics of Mindanao Southern Philippines. Geomorphology, 9, 325-342. http://dx.doi.org/10.1016/0169-555X(94)90053-1

[45] Rekhiss, F. (2007) Modèle d'Evolution Structurale et Géodyna- mique à l'Extrémité Orientale de la Chaine Alpine d'Afrique du Nord. Thèsed'Etat en Géologie, Université de Tunis El Manar, Tunis.

[46] Jallouli, C., Inoubli, M.H. and Albouy, Y.Y. (1996) Le corps igné de Nefza (Tunisie septentrionale): caractéristiques géophysiques et discussion du mécanisme de sa mise en place. Notes du service Géologique de Tunisie No. 62, 109123.

[47] Dlala, M. (1994) Evidence for Interchange of the Stress $(\sigma 1, \sigma 2)$ and Its Geodynamic Implication: Rock View, African Geoscience, 1, 533-545.

[48] Dlala, M. (1995) Evolution géodynamique et tectonique superposées en Tunisie implications sur la tectonique récente et la sismicité. Tunis University, Tunis.

[49] Dlala, M. and Kacem, J. (2008) Alea Sismique régional du grand Tunis et ses Environs (Tunisie Nord Orientale). Annales de l'équipement, 13-27.

[50] Kamoun, Y. (1981) Etude néotectonique dans la région de Monastir-Mahdia (Tunisie orientale). Thèse 3ème Cycle, Université Paris-Sud, Orsay, 185 p.

[51] Dlala, M. (1984) Tectonique récente et microtectonique de la région de Kasserine (Tunisie Centrale). University Technology Services, de Languedoc, Montpellier.

[52] Ben Ayed, N. (1986) Evolution Tectonique de l'avant pays de la chaîne alpine de Tunisie du début du Mésozoïque a’ l'Actuel. Thèse Doc, Etat, Université Paris-Sud, Paris, 328 p.

[53] Zargouni, F. and Trimolière, P. (1981) Déformation tectonique postérieure au dépôt de la série du Ségui (PlioVillafrachien) dans l'Atlas méridional tunisien. Résumé du premier Congr, Nat. Sc, Terre, Tunis, 59.

[54] Zargouni, F. (1985) Tectonique de l'Atlas méridional de Tunisie, évolution géomeétrique et cinématique des structures en zone de cisaillement. Edit. Mem. INRST. 5, Vol. 3, Thèse Doc. Etat, Université Louis Pasteur, Strasbourg, 302 p.

[55] Vially, R., Letouzey, J., Benard, F., Haddadi, N., Desforges, G., Askri, H. and Boudjema, A. (1994) Basin Inversion along the North African Margin: The Saharan Atlas. In: Roure, F., Ed., Peri-Tethys Platforms, Technip, Paris, 79-118. 